\title{
Estimation of copepod trophic niche in the field using amino acids and marker pigments
}

\author{
Cástor Guisande ${ }^{1, *}$, Isabel Maneiro ${ }^{1}$, Isabel Riveiro ${ }^{1}$, Aldo Barreiro ${ }^{1}$, \\ Yolanda Pazos ${ }^{2}$ \\ ${ }^{1}$ Facultad de Ciencias del Mar, Universidad de Vigo, Lagoas-Marcosende, 36200 Vigo, Spain \\ ${ }^{2}$ Centro de Control de Calidade do Medio Mariño, Consellería de Pesca, Marisqueo e Acuicultura, Peirao de Vilaxoán, \\ 36611 Vilagarcía, Spain
}

\begin{abstract}
In this study, marker pigments analysed in incubation feeding experiments and monthly amino acid composition (AAC, weight percentage of total amino acids yields) of copepods collected over $1 \mathrm{yr}$ from the field were used to estimate the food niche of 4 co-occurring copepod species: Acartia clausi, Oithona nana, Temora longicornis and Euterpina acutifrons. Both marker pigments and AAC of copepods are good indicators of copepod food niche. Marker pigments are indicators of the autotrophic food ingested by copepods and AAC is an indicator of both autotrophic and nonautotrophic food needed by copepods to maximise reproductive success. Marker pigments showed that copepod species fed selectively on the phytoplankton community and that copepod species had different diets. A. clausi fed mainly on chlorophytes and diatoms, E. acutifrons on diatoms and chlorophytes, T. longicornis on dinoflagellates and diatoms, and O. nana on dinoflagellates and prymnesiophytes. Each copepod species had its own specific AAC and, furthermore, there was a significant relationship between similarity in AAC among copepod species and similarity in the phytoplankton classes ingested by them, indicating that the differences in the AAC among copepod species were due to different food resources. As a higher copepod reproductive success is observed when the AAC of the food is more similar to the AAC of the copepods, this selective feeding behaviour could be due to the necessity of a diet with an AAC balanced in an optimal proportion. The food niche partitioning observed in this study might contribute to the coexistence of these copepod species in their habitat.
\end{abstract}

KEY WORDS: Copepods $\cdot$ Food niche $\cdot$ Amino acids $\cdot$ Pigments $\cdot$ CHEMTAX program

Resale or republication not permitted without written consent of the publisher

\section{INTRODUCTION}

The estimation of copepod species' diet in the field is critical for understanding some aspects of copepod ecology that still remain unclear. Food niche quantification could help to determine whether copepods are selective feeders in nature, because as yet, the results obtained are contradictory showing selective (Keppel et al. 1996, Meyer-Harms \& von Bodungen 1997, MeyerHarms et al. 1999) and non-selective (Turner \& Tester 1989, Irigoien et al. 2000) feeding behaviour in copepod species. Food niche differences might reduce

*E-mail: castor@uvigo.es exploitative competition, but the importance of trophic niche separation on the coexistence of copepod species in nature is still unknown. The question of whether copepods have different food niches in their habitat is also important due to the implications of a selective or non-selective feeding behaviour on flows of energy and materials through food webs.

Control experiments using different techniques have clearly demonstrated food niche differences among zooplankton species (see Bogdan \& Gilbert 1987). However, as mentioned by Turner \& Tester (1989), although some copepod species are capable of distinguishing between a limited number of food alternatives in the laboratory, it does not imply that they feed 
the same way when exposed to a plethora of different food items in their habitat.

Food niche quantification in the field is difficult due to the taxonomic and biochemical complexity of the food environment. Marker pigments measured at the beginning and end of incubation feeding experiments have been revealed as a useful tool for estimating copepod diet in the field (Meyer-Harms \& von Bodungen 1997, Irigoien et al. 2000). Marker pigments allow the identification of taxonomic groups of the phytoplankton community (Mackey et al. 1996, Wright et al. 1996, Schlüter et al. 2000) and, hence, the estimation of taxon-specific grazing activity of copepods. Moreover, the CHEMTAX program developed by Mackey et al. (1996) facilitates the determination of the abundance and composition of phytoplankton groups from marker pigments.

Amino acid composition (AAC, weight percentage of total amino acids yields) of copepods could also be used to determine copepod diet in the field. Guisande et al. (2000) showed that AAC in Euterpina acutifrons adults in the field was relatively constant despite different nutritional supplies. Moreover, it was shown that AAC of the diet was important for E. acutifrons, because a higher reproductive success was observed when AAC of copepods and their food was similar (Guisande et al. 1999, 2000). If other copepod species show a rigid AAC, as has been observed in E. acutifrons, and AAC of copepods is species-specific, then AAC of the copepod species could be an indicator of the diet of each copepod species.

The most abundant herbivorous copepod species in the Ría de Vigo (NW Spain), Acartia clausi, Oithona nana, Temora longicornis and Euterpina acutifrons, can exploit a similar class of food resources, mainly phytoplankton with a size range between 3 and $100 \mu \mathrm{m}$ (Kinne 1977, Donaghay \& Small 1979, Hansen et al. 1994). As herbivorous copepods are food-limited in this area during some times of the year (Guisande et al. 2000), then according to niche theory, coexistence of these species could be possible due to niche partitioning. Therefore, niche separation of these 4 co-occurring copepod species could be partly due to a trophic separation.

The aim of this study was to determine whether it is possible to quantify the food niche of these species in the field by using marker pigments and/or AAC of copepods, as well as to determine whether there is a trophic separation among these copepod species.

\section{MATERIALS AND METHODS}

Amino acid analysis of copepods. From February 1998 to March 1999, amino acid analyses were carried out on copepods monthly at the station located in the
Ría de Vigo (NW Spain, 42 $13.3^{\prime} \mathrm{N}, 8^{\circ} 47.7^{\prime} \mathrm{W}, 29 \mathrm{~m}$ depth). Copepods were collected by oblique integrated tows from $20 \mathrm{~m}$ depth to the surface with a $50 \mathrm{~cm}$ diameter Bongo sampler equipped with a $20 \mu \mathrm{m}$ mesh. AA analyses of copepods were performed on adults isolated within $2 \mathrm{~h}$ of collection. The AA analysis of a copepod species was performed if there were more than 10 individuals of this species (in order to have several replicates of the AAC for each species) in the zooplankton sample collected from the field and 5 adults were used for Oithona nana, 3 for Euterpina acutifrons and 2 each for Temora longicornis and Acartia clausi. AAC was analysed by high-performance liquid chromatography (HPLC) using a Waters Alliance system in conjunction with a Waters 474 scanning fluorescence detector and $15 \times 3.9$ Nova-Pak $\mathrm{C}_{18}$ column (Van Wandelen \& Cohen 1997). This AA analysis constitutes an acid hydrolysis followed by conversion of the AA to fluorescently labelled amines. All AA analysed were isolated at the same efficiency (Van Wandelen \& Cohen 1997). AA Standard H NCI0180 (Pierce) was used for the identification and quantification purposes.

Grazing experiments. Phytoplankton assemblage for grazing experiments were collected from $10 \mathrm{~m}$ depth on 28 December 2000, 18 January 2001 and 15 February 2001 at the station mentioned above. Water samples were sieved through a $100 \mu \mathrm{m}$ mesh net, and this phytoplankton fraction was used as food suspension. Water samples were not enriched with nutrients prior to the experiment. Experiments were carried out in $75 \mathrm{ml}$ plastic jars with $65 \mathrm{ml}$ of the food suspension and 2 Temora longicornis, 2 Acartia clausi, 3 Euterpina acutifrons and/or 3 Oithona nana, and the number of replicates varied according to the abundance of copepod species in the sample. In December 2000, only A. clausi and T. longicornis were used, in January 2001, A. clausi, T. longicornis and E. acutifrons, and in February 2001, all species were present in the field. To determine the initial phytoplankton composition, 4 replicates of $300 \mathrm{ml}$ of the food suspension were filtered through $13 \mathrm{~mm}$ Whatman GF/C filters (around $1.2 \mu \mathrm{m}$ pore size) and then lyophilised and stored at $-80^{\circ} \mathrm{C}$ in ultracentrifuge plastic tubes until pigments analysis by HPLC. Between 8 to 20 plastic jars for each copepod species and between 15 and 20 controls were incubated with shaking $(60 \mathrm{rpm})$ at $15^{\circ} \mathrm{C}$ under a $12: 12 \mathrm{~h}$ light:dark cycle. After $24 \mathrm{~h}$, individuals were checked for mortality, though no mortality was found in any of the experiments. The water of control and experimental jars were sieved again though $100 \mu \mathrm{m}$ mesh and then, $60 \mathrm{ml}$ were taken from each control and experimental jar. Four to 5 of the $60 \mathrm{ml}$ samples for the control and experimental jars were separately pooled, after which they were filtered, lyophilised and stored as mentioned above. Therefore, the total volume filtered 
through each filter ranged between 240 and $300 \mathrm{ml}$, and the size fraction analysed was between 1.2 and $100 \mu \mathrm{m}$. The rest of the food suspension of the control and experimental jars as well as water from the initial food suspension was preserved in Lugol's iodine for phytoplankton cell counting with an inverted microscope and estimation of phytoplankton cell volumes.

Cell volumes of phytoplankton species. Cell volumes of the phytoplankton species were determined by approximation to the nearest geometric shape (Edler 1979, Hillebrand et al. 1999). Table 1 shows cell volumes of the phytoplankton species found during the period studied in the size fraction $<100 \mu \mathrm{m}$ used for grazing experiments. Volume was converted to carbon content according to the equations given by MendenDeuer \& Lessard (2000).

Pigment composition of phytoplankton assemblage. Pigments extraction was done by adding $2 \mathrm{ml}$ 95\% methanol to the lyophilised material. Then the sample was homogenised using a pipette tip adapted to fit the shape of the vial. Marker pigments were analysed following Zapata et al. (2000). Pigment profiles were determined by HPLC using a Waters Alliance System in conjunction with a Waters 996 photodiode array detector and Symmetry $\mathrm{C}_{8}$ column $(150 \times 4.6 \mathrm{~mm}$, $3.5 \mu \mathrm{m}$ particle size, $100 \AA$ pore size).

The contribution of each major phytoplanktonic taxon to chlorophyll a ( $\mathrm{chl}$ a) was calculated by using the CHEMTAX program developed by Mackey et al. (1996). Table 2 shows the initial pigment:chl a ratio matrix used in this study (which is a modification of that reported by Mackey et al. 1996) and the output ratio matrix generated by CHEMTAX. The 2 lightprotecting pigments, diadinoxanthin and diatoxanthin, and ambiguous pigments that are in many algal classes were not included. Due to the presence in the

Table 1. Cell volumes (in $\mu^{3}$ ) of the most abundant phytoplankton species present in the food suspension $(<100 \mu \mathrm{m})$ used for the grazing experiments

\begin{tabular}{|c|c|c|c|}
\hline & Cell volume $\left(\mu \mathrm{m}^{3}\right)$ & & Cell volume $\left(\mu \mathrm{m}^{3}\right)$ \\
\hline Diatoms & & Dinoflagellates & \\
\hline Actinoptychus splendes & 596259 & Amphidinium flagellans & 2741 \\
\hline Asteromphalus flabellatus & 49507 & Cachonina spp. & 874 \\
\hline Asterionellopsis glacialis & 1657 & Ceratium azoricum & 50265 \\
\hline Odontella mobiliensis & 88908 & Ceratium furca & 108334 \\
\hline Corethron hystrix & 2719 & Ceratium fusus & 21151 \\
\hline Coscinodiscus spp. & 164710 & Ceratium horridum & 588165 \\
\hline Chaetoceros curvisetus & 2046 & Cochlodinium pulchellum & 22095 \\
\hline Chaetoceros decipiens & 6230 & Cochlodinium spp. & 5969 \\
\hline Chaetoceros spp. & 2400 & Dinophysis caudata & 357486 \\
\hline Detonula pumila & 13530 & Dinophysis mucronata & 16817 \\
\hline Diploneis spp. & 44935 & Dinophysis ovum & 24211 \\
\hline Fragilaria crotonensis & 543 & Diplopsalis spp. & 44935 \\
\hline Grammatophora marina & 3691 & Karenia mikimotoi & 964 \\
\hline Guinardia delicatula & 1653 & Gonyaulax grindleyi & 24330 \\
\hline Podosira stelliger & 63277 & Gymnodinium spp. & 1403 \\
\hline Melosira islandica & 946 & Gyrodinium fusiforme & 22084 \\
\hline Paralia sulcata & 946 & Gyrodinium spp. & 1403 \\
\hline Navicula spp. & 1594 & Oblea spp. & 13804 \\
\hline Nitzschia longissima & 177 & Xytoxum crassum & 2681 \\
\hline Pleurosigma angulatum & 35327 & Oxytoxum scolopax & 5219 \\
\hline Pleurosigma elongatum & 15866 & Phalacroma rotundatum & 55727 \\
\hline Pseudo-nitzschia spp. & 1847 & Podolampas palmipes & 21721 \\
\hline Skeletonema costatum & 291 & Prorocentrum micans & 6493 \\
\hline Thalassionema frauenfeldii & 2512 & Protoperidinium bipes & 11100 \\
\hline Thalassionema nitzschioides & 2512 & Protoperidinium crassipes & 177935 \\
\hline \multirow[t]{2}{*}{ Thalassiosira spp. } & 11056 & Protoperidinium diabolum & 53107 \\
\hline & & Protoperidinium divergens & 116356 \\
\hline Ciliates & & Pyrocystis lunula & 20610 \\
\hline Halteria spp. & 2806 & Scrippsiella trochoidea & 5994 \\
\hline Mesodinium rubrum & 29015 & Torodinium robustum & 12566 \\
\hline Stenosemella ventricosa & 99105 & & \\
\hline Strombidium constrictum & 16822 & Euglenophytes & \\
\hline Strombidium delicatissimum & 1387 & Eutreptiella gymnastica & 571 \\
\hline Tiarina fusus & 2169 & Eutreptiella spp. & 571 \\
\hline Tintinnopsis beroidea & 37292 & & \\
\hline Tintinnopsis nana & 5771 & Small flagellates & 254 \\
\hline
\end{tabular}


algal counts of autotrophic peridinin-lacking dinoflagellates (Gymnodinium spp.) that have both 19'-hexanoyloxyfucoxanthin and 19'-butanoyloxyfocoxanthin (Zapata et al. 1998), the 'chemotaxonomic group' described by Rodriguez et al. (2002) was introduced in the pigment ratio matrix (Table 2). The concentration

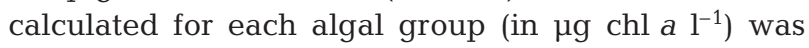
used to estimate the taxon-specific grazing rates as according to Frost (1972).

Selectivity index. Manly's selectivity index $\left(\alpha_{I}\right)$ (Manly 1974) was used to measure dietary preference of copepod species of the different taxonomic phytoplankton groups:

Table 2. Initial and final pigment/chlorophyll a ratios for diatoms (DIAT), cyanobacterias (CYAN), dinoflagellates (DINO), prymnesiophytes (PRYM), chemotaxonomic group (CHEM), chlorophytes (CHLO), cryptophytes (CRYP) and prasinophytes (PRAS) used in the CHEMTAX program. Pigment abbreviations: chl a (chlorophyll $a$ ), chl $b$ (chlorophyll $b$ ), chl $c_{1}$ (chlorophyll $\left.c_{1}\right)$, chl $c_{2}$ (chlorophyll $c_{2}$ ), chl $c_{3}$ (chlorophyll $c_{3}$ ), PER (peridinin), BUT (19'-butanoyloxyfucoxanthin), FUC (fucoxanthin), HEX (19'-hexanoyloxyfucoxanthin), NEO (neoxanthin), PRA (prasinoxanthin), VIO (violaxanthin), ALL (alloxanthin), LUT (lutein) and ZEA (zeaxanthin)

\begin{tabular}{|c|c|c|c|c|c|c|c|c|}
\hline & DIAT & CYAN & DINO & PRYM & CHEM & CHLO & CRYP & PRAS \\
\hline \multicolumn{9}{|c|}{ Initial ratio matrix } \\
\hline Chl a & 1.000 & 1.000 & 1.000 & 1.000 & 1.000 & 1.000 & 1.000 & 1.000 \\
\hline Chl $b$ & 0.000 & 0.000 & 0.000 & 0.000 & 0.000 & 0.414 & 0.000 & 0.821 \\
\hline Chl $c_{1}$ & 0.102 & 0.000 & 0.000 & 0.000 & 0.000 & 0.000 & 0.000 & 0.000 \\
\hline $\mathrm{Chl} C_{2}$ & 0.116 & 0.000 & 0.532 & 0.180 & 0.126 & 0.000 & 0.063 & 0.000 \\
\hline $\mathrm{Chl} C_{3}$ & 0.000 & 0.000 & 0.000 & 0.296 & 0.067 & 0.000 & 0.000 & 0.000 \\
\hline PER & 0.000 & 0.000 & 1.065 & 0.000 & 0.000 & 0.000 & 0.000 & 0.000 \\
\hline BUT & 0.000 & 0.000 & 0.000 & 0.009 & 0.122 & 0.000 & 0.000 & 0.000 \\
\hline FUC & 0.538 & 0.000 & 0.000 & 0.301 & 0.290 & 0.000 & 0.000 & 0.000 \\
\hline $\mathrm{NEO}$ & 0.000 & 0.000 & 0.000 & 0.000 & 0.000 & 0.057 & 0.000 & 0.097 \\
\hline PRA & 0.000 & 0.000 & 0.000 & 0.000 & 0.000 & 0.000 & 0.000 & 0.143 \\
\hline VIO & 0.000 & 0.000 & 0.000 & 0.000 & 0.000 & 0.046 & 0.000 & 0.032 \\
\hline HEX & 0.000 & 0.000 & 0.000 & 0.426 & 0.248 & 0.000 & 0.000 & 0.000 \\
\hline ALL & 0.000 & 0.000 & 0.000 & 0.000 & 0.000 & 0.000 & 0.205 & 0.000 \\
\hline ZEA & 0.000 & 0.489 & 0.000 & 0.000 & 0.000 & 0.059 & 0.000 & 0.076 \\
\hline LUT & 0.000 & 0.000 & 0.000 & 0.000 & 0.000 & 0.187 & 0.000 & 0.017 \\
\hline \multicolumn{9}{|c|}{ Output ratio matrix } \\
\hline Chl a & 1.000 & 1.000 & 1.000 & 1.000 & 1.000 & 1.000 & 1.000 & 1.000 \\
\hline Chl $b$ & 0.000 & 0.000 & 0.000 & 0.000 & 0.000 & 0.414 & 0.000 & 0.820 \\
\hline $\mathrm{Chl} c_{1}$ & 0.025 & 0.000 & 0.000 & 0.000 & 0.000 & 0.000 & 0.000 & 0.000 \\
\hline $\mathrm{Chl} C_{2}$ & 0.093 & 0.000 & 0.532 & 0.180 & 0.126 & 0.000 & 0.063 & 0.000 \\
\hline $\mathrm{Chl} \mathrm{C}_{3}$ & 0.000 & 0.000 & 0.000 & 0.296 & 0.067 & 0.000 & 0.000 & 0.000 \\
\hline PER & 0.000 & 0.000 & 1.111 & 0.000 & 0.000 & 0.000 & 0.000 & 0.000 \\
\hline BUT & 0.000 & 0.000 & 0.000 & 0.009 & 0.122 & 0.000 & 0.000 & 0.000 \\
\hline FUC & 0.434 & 0.000 & 0.000 & 0.301 & 0.290 & 0.000 & 0.000 & 0.000 \\
\hline $\mathrm{NEO}$ & 0.000 & 0.000 & 0.000 & 0.000 & 0.000 & 0.057 & 0.000 & 0.110 \\
\hline PRA & 0.000 & 0.000 & 0.000 & 0.000 & 0.000 & 0.000 & 0.000 & 0.058 \\
\hline VIO & 0.000 & 0.000 & 0.000 & 0.000 & 0.000 & 0.046 & 0.000 & 0.032 \\
\hline HEX & 0.000 & 0.000 & 0.000 & 0.291 & 0.248 & 0.000 & 0.000 & 0.000 \\
\hline ALL & 0.000 & 0.000 & 0.000 & 0.000 & 0.000 & 0.000 & 0.205 & 0.000 \\
\hline ZEA & 0.000 & 0.489 & 0.000 & 0.000 & 0.000 & 0.059 & 0.000 & 0.044 \\
\hline LUT & 0.000 & 0.000 & 0.000 & 0.000 & 0.000 & 0.187 & 0.000 & 0.017 \\
\hline
\end{tabular}

$$
\alpha_{i}=\frac{\log \frac{e_{i}}{n_{i}}}{\sum_{j=1}^{m} \log \frac{e_{j}}{n_{j}}}
$$

where $\alpha$ is the selectivity index for each phytoplankton group $i, n$ is the mean between initial and final concen-

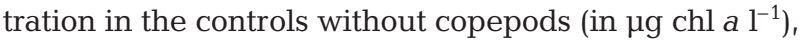
$e$ is the final concentration in the experimental jars with copepods, $m$ is the number of phytoplankton groups, nd $j$ is a phytoplankton group. When the concentration of a phytoplankton group increased in the experimental bottles with copepods compared to the controls, $\alpha$ was considered to be 0 . There is $1 \alpha_{i}$ for each phytoplankton group and the sum of all $\alpha_{i}$ is 1 .

Statistical analyses. A discriminant analysis using SPSS was performed to determine whether there were significant differences among the AAC of copepod species and among marker pigments in the incubation grazing experiments. Euclidean distance $\left(D_{j k}\right)$ was used to determine the similarity among copepod species in their AAC and in marker pigments in grazing experiments:

$$
D_{i j}=\sqrt{\frac{\left(X_{i 1}-X_{j 1}\right)^{2}+\left(X_{i 2}-X_{j 2}\right)^{2}}{2}}
$$

where $X$ is the mean of the scores for the Axes 1 and 2 obtained from a discriminant analysis performed on the copepod AAC or marker pigments, for the species $i$ and $j$. A higher similarity is obtained when the Euclidean distance is smaller.

\section{RESULTS}

Table 3 shows the mean AAC of each copepod species during the period of the study. If copepod species are grouped according to their AAC, a discriminant analysis shows that it is possible to identify each copepod species according to its AAC (Fig. 1). The first and second components accounted for 57.4 and $34.2 \%$ of the variance, respectively. Acartia clausi and Oithona nana do not appear to be separated (Fig. 1) because this figure only shows the first and second components of the discriminant analysis. 
Table 3. Amino acid composition (mean \pm SD weight percentage of total amino acids yields) of Acartia clausi, Euterpina acutifrons, Temora longicornis and Oithona nana from February 1998 to March 1999. Amino acid abbreviations: ASP (aspartic acid), SER (serine), GLU (glutamic acid), GLY (glycine), HIS (histidine), ARG (arginine), THR (threonine), ALA (alanine), PRO (proline), TYR (tyrosine), VAL (valine), LYS (lysine), ILE (isoleucine), LEU (leucine) and PHE (phenylananine)

\begin{tabular}{|lrrrr|}
\hline & $\begin{array}{c}\text { Acartia } \\
\text { clausi }\end{array}$ & $\begin{array}{r}\text { Euterpina } \\
\text { acutifrons }\end{array}$ & $\begin{array}{c}\text { Temora } \\
\text { longicornis }\end{array}$ & \multicolumn{1}{c|}{$\begin{array}{c}\text { Oithona } \\
\text { nana }\end{array}$} \\
\hline ASP & $10.0 \pm 1.1$ & $8.9 \pm 0.5$ & $10.0 \pm 1.0$ & $9.6 \pm 1.4$ \\
SER & $4.7 \pm 0.4$ & $4.9 \pm 0.6$ & $5.2 \pm 0.4$ & $5.7 \pm 1.6$ \\
GLU & $14.5 \pm 0.5$ & $14.1 \pm 0.9$ & $13.8 \pm 0.7$ & $15.5 \pm 0.7$ \\
GLY & $8.4 \pm 1.6$ & $6.6 \pm 0.7$ & $7.5 \pm 0.6$ & $9.6 \pm 0.8$ \\
HIS & $2.8 \pm 0.2$ & $2.6 \pm 0.2$ & $2.8 \pm 0.2$ & $2.8 \pm 0.2$ \\
ARG & $8.1 \pm 0.8$ & $9.4 \pm 1.2$ & $8.3 \pm 1.1$ & $6.7 \pm 1.0$ \\
THR & $5.1 \pm 0.3$ & $4.9 \pm 0.4$ & $5.3 \pm 0.2$ & $4.8 \pm 0.3$ \\
ALA & $7.6 \pm 0.5$ & $7.9 \pm 0.4$ & $7.7 \pm 0.9$ & $7.0 \pm 0.6$ \\
PRO & $4.6 \pm 0.6$ & $5.9 \pm 0.8$ & $6.1 \pm 1.3$ & $4.6 \pm 0.6$ \\
TYR & $5.1 \pm 0.8$ & $6.9 \pm 1.1$ & $6.1 \pm 0.9$ & $5.7 \pm 1.0$ \\
VAL & $5.2 \pm 0.3$ & $5.4 \pm 0.2$ & $5.6 \pm 0.3$ & $5.0 \pm 0.3$ \\
LYS & $7.8 \pm 0.5$ & $7.5 \pm 0.6$ & $7.0 \pm 0.6$ & $8.0 \pm 0.8$ \\
ILE & $4.8 \pm 0.3$ & $4.9 \pm 0.4$ & $4.5 \pm 0.2$ & $4.7 \pm 0.4$ \\
LEU & $7.3 \pm 0.3$ & $7.0 \pm 0.3$ & $6.6 \pm 0.4$ & $6.9 \pm 0.3$ \\
PHE & $3.9 \pm 0.2$ & $3.3 \pm 0.5$ & $3.8 \pm 0.2$ & $3.5 \pm 0.3$ \\
\hline
\end{tabular}

Table 4. Results of a discriminant analysis showing the percentage of copepod species correctly classified according to their amino acid composition. Acartia clausi (A.c.), Euterpina acutifrons (E.a.), Temora longicornis (T.1.) and Oithona nana (O.n.)

\begin{tabular}{|lrrrc|}
\hline \multirow{2}{*}{ Actual group } & \multicolumn{4}{c|}{ Predicted groups } \\
& A.c. & E.a. & T.l. & O.n. \\
\hline A.c. & 100 & 0 & 0 & 0 \\
E.a. & 0 & 100 & 0 & 0 \\
T.l. & 0 & 0 & 100 & 0 \\
O.n. & 9.1 & 0 & 0 & 90.9 \\
\hline
\end{tabular}

Table 5. Factor loadings for the 2 principal components of a discriminant analysis for the amino acid composition of copepod species. Amino acid abbreviations are given in Table 3

\begin{tabular}{|lrr|}
\hline & Factor 1 & Factor 2 \\
\hline ASP & -0.177 & -0.163 \\
SER & 0.029 & -0.086 \\
GLU & -0.159 & 0.163 \\
GLY & -0.315 & -0.017 \\
HIS & -0.173 & -0.125 \\
ARG & 0.227 & 0.101 \\
THR & -0.063 & -0.201 \\
ALA & 0.097 & 0.007 \\
PRO & 0.269 & -0.187 \\
TYR & 0.288 & 0.040 \\
VAL & 0.173 & -0.287 \\
LYS & -0.105 & 0.225 \\
ILE & 0.007 & 0.266 \\
LEU & -0.141 & 0.363 \\
PHE & -0.289 & -0.199 \\
\hline
\end{tabular}
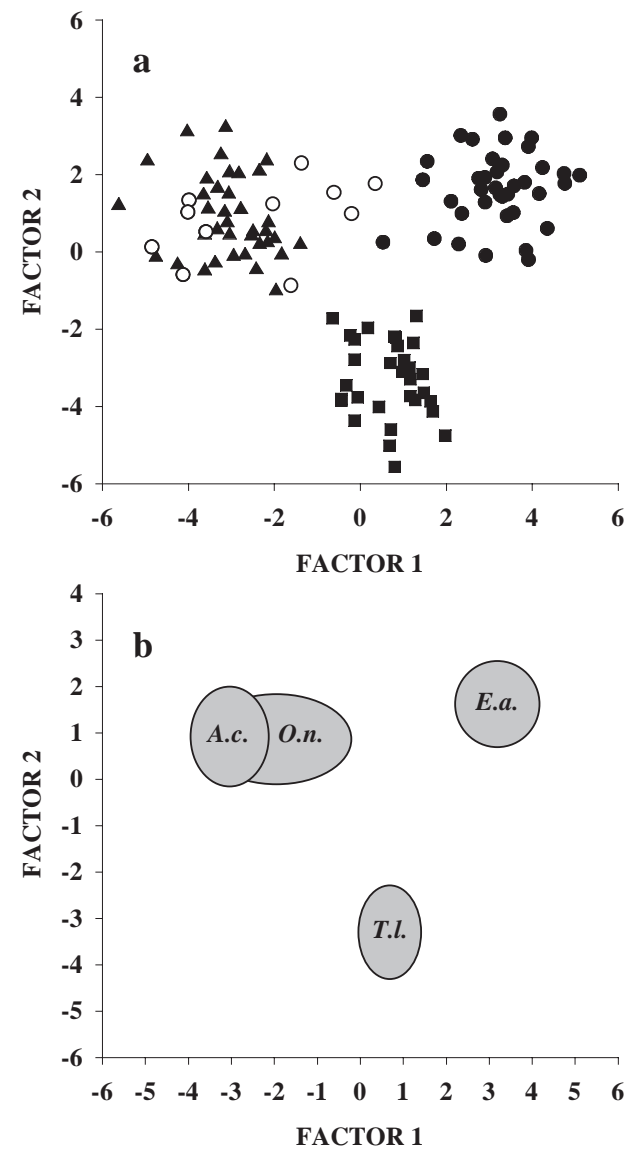

Fig. 1. Plots of the first 2 discriminant analysis scores for (a) the amino acid composition of copepod species obtained during the period of this study and (b) the mean \pm SD of the scores. Acartia clausi (4), Oithona nana (O), Temora longicornis (घ) and Euterpina acutifrons $(\bullet)$

Considering all components of the discriminant analysis, the percent of copepod species correctly classified according to their AAC was $99.1 \%$ of all cases. Table 4 shows that only some individuals of $O$. nana were classified as A. clausi. Copepod species mainly differ in the proportions of ASP, GLY, HIS, PRO, TYR, VAL and LEU present (Table 5).

Table 6 shows the percentage of each major phytoplankton group in the phytoplankton assemblage $(<100 \mu \mathrm{m})$ used for grazing experiments, estimated by phytoplankton cell counting. In December 2000 and January 2001, most of the phytoplankton community was dominated by species with a small size that could not be identified by microscopic counting. In February 2001, there was a bloom of the diatom Skeletonema costatum which constituted approximately $74 \%$ total carbon. Total carbon, estimated from cell counting, showed that food concentration was low in December 2000 and January 2001 compared to February (Table 6). The mean \pm SD C:chl a ratio was $48.6 \pm 26.5$. 
Table 6. Total carbon estimated from cell counting, percentage of different taxonomic groups from total carbon and the mean \pm SE chl $a$ of the size fraction 1.2 to $100 \mu \mathrm{m}$ collected from the field for grazing experiments. Dates: $\mathrm{dd} / \mathrm{mm} / \mathrm{yy}$

\begin{tabular}{|lccc|}
\hline & $28 / 12 / 01$ & $18 / 01 / 01$ & $15 / 02 / 01$ \\
\hline Total carbon $\left(\mu \mathrm{g} \mathrm{l}^{-1}\right)$ & 6.3 & 29.2 & 123.9 \\
Diatoms $(\%)$ & 18.4 & 6.8 & 75.9 \\
Dinoflagellates (\%) & 6.3 & 4.9 & 6.0 \\
Euglenophytes (\%) & 0.0 & 0.1 & 0.1 \\
Ciliates (\%) & 0.0 & 7.3 & 6.2 \\
Unknown flagellates (\%) & 75.3 & 80.9 & 11.8 \\
Chl $a\left(\mathrm{~g} \mathrm{l}^{-1}\right)$ & $0.27 \pm 0.02$ & $1.0 \pm 0.05$ & $1.7 \pm 0.15$ \\
\hline
\end{tabular}
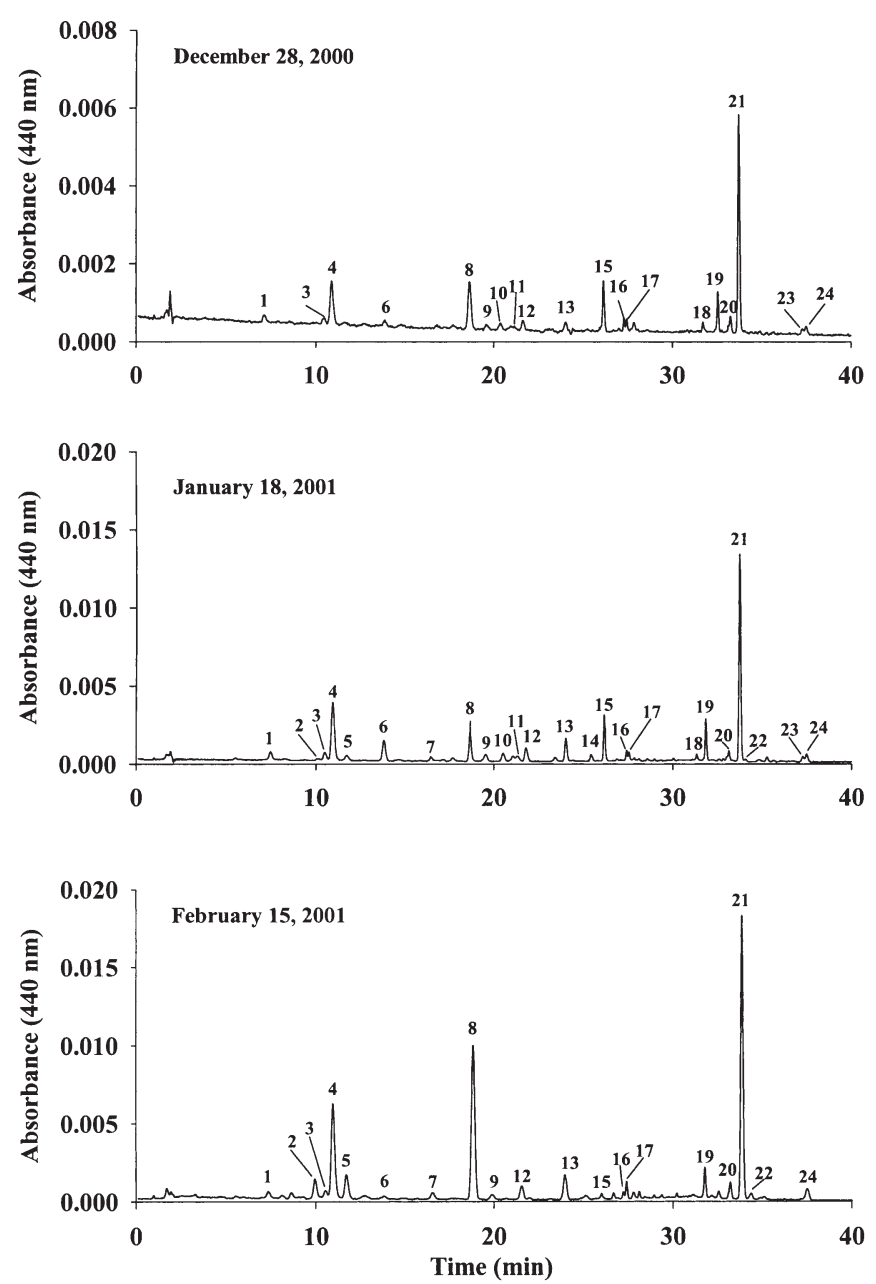

Fig. 2. Pigment composition of the field phytoplankton size fraction (1.2 to $100 \mu \mathrm{m})$ used as food on grazing experiments. Peak identifications: 1 (Chlorophyll $c_{3}$ ), 2 (Chlorophyllide $a$ ), 3 (Mg 3,8 divinyl pheoporphyrin $\left.a_{5}\right), 4$ (Chlorophyll $C_{2}$ ), 5 (Chlorophyll $c_{1}$ ), 6 (Peridinin), 7 Pheophorbide $a_{1} 8$ (Fucoxanthin), 9 (Neoxanthin), 10 (Prasinoxanthin), 11 (Violaxanthin), 12 (19'-Hexanoyloxyfucoxanthin), 13 (Diadinoxanthin), 14 (Dinoxanthin), 15 (Alloxanthin), 16 (Zeaxanthin), 17 (Lutein), 18 (Crocoxanthin), 19 (Chlorophyll b), 20 (Chlorophyll a allomer), 21 (Chlorophyll $a), 22$ (Chlorophyll a epimer), $23(\beta, \varepsilon$-carotene) and $24(\beta, \beta$-carotene $)$
Table 7. Percentage of different taxonomic groups calculated by the CHEMTAX program from marker pigments of the size fraction $<100 \mu \mathrm{m}$ collected from the field for grazing experiments. Dates: dd/mm/yy

\begin{tabular}{|lccc|}
\hline & $28 / 12 / 00$ & $18 / 01 / 01$ & $15 / 02 / 01$ \\
\hline Diatoms & 15.35 & 14.1 & 72.44 \\
Cyanobacterias & 0.00 & 0.00 & 0.3 \\
Dinoflagellates & 4.22 & 13.66 & 1.73 \\
Prymnesiophytes & 5.27 & 7.98 & 7.05 \\
Chlorophytes & 8.35 & 2.16 & 2.31 \\
Chryptophytes & 22.8 & 25.47 & 6.42 \\
Prasinophytes & 34.78 & 36.63 & 6.84 \\
Chemotaxonomic group & 9.24 & 0.00 & 2.91 \\
\hline
\end{tabular}

Fig. 2 shows pigment profiles of the phytoplankton assemblage used for grazing experiments. Table 7 shows the percentage of algal groups calculated by CHEMTAX program from marker pigments. It was not possible to compare algal classes estimated by microscopical examination with those calculated by the CHEMTAX program because small algal cells were the predominant group in December and January. Schlüter et al. (2000) also pointed out the problem with comparing phytoplankton groups calculated by the CHEMTAX program with those obtained on the basis of microscopic analyses when small flagellates dominate phytoplankton community.

A discriminant analysis showed that it is possible to identify the diet of each copepod species from marker pigments (Fig. 3a) and from phytoplankton groups calculated by the CHEMTAX program (Fig. 3b), indicating that copepod species fed selectively on the phytoplankton community. The percent of copepod species correctly classified according to marker pigments was $100 \%$ for all cases in December, January and February. Accordingly, phytoplankton groups calculated by the CHEMTAX program were $100 \%$ in December, $86.7 \%$ in January and $80 \%$ of all cases in February. Therefore, a better discrimination of food niche among copepod species was achieved using marker pigments rather than the phytoplankton groups estimated by the CHEMTAX program. However, to obtain information about the taxon-specific grazing activity of copepods, it is necessary to use the CHEMTAX program.

Fig. 4 shows, for each copepod species, the relationships between the ingestion and the concentration of the most abundant phytoplankton groups, diatoms, dinoflagellates, prymnesiophytes, chryptophytes, chlorophytes and prasinophytes (Table 7) present on the 3 sampling days. Fig. 5 shows the selectivity index values for the different phytoplankton taxa. A 1-way analysis of variance (ANOVA), using the different phytoplankton groups as the factor and the selectivity index values as the dependent variable, showed that 
phytoplankton groups were selectively ingested by Acartia clausi $\left(F_{5,54}=3.3, \mathrm{p}=0.011\right)$, Euterpina acutifrons $\left(F_{5,36}=3.1, \mathrm{p}=0.018\right)$, Temora longicornis $\left(F_{5,58}=4.4, \mathrm{p}=0.002\right)$ and Oithona nana $\left(F_{5,12}=4.2\right.$, $\mathrm{p}=0.023)$. Moreover, copepod species had different food niches, because a 2-way ANOVA, taking into in account the different phytoplankton groups and species as factors and the selectivity index values as the dependent variable, showed that there were significant differences in the diet among copepod species in December $\left(F_{5,21}=4.2, \mathrm{p}=0.007\right)$, January $\left(F_{10,34}=2.3\right.$, $\mathrm{p}=0.031)$ and February $\left(F_{15,71}=2.2, \mathrm{p}=0.014\right) . A$.
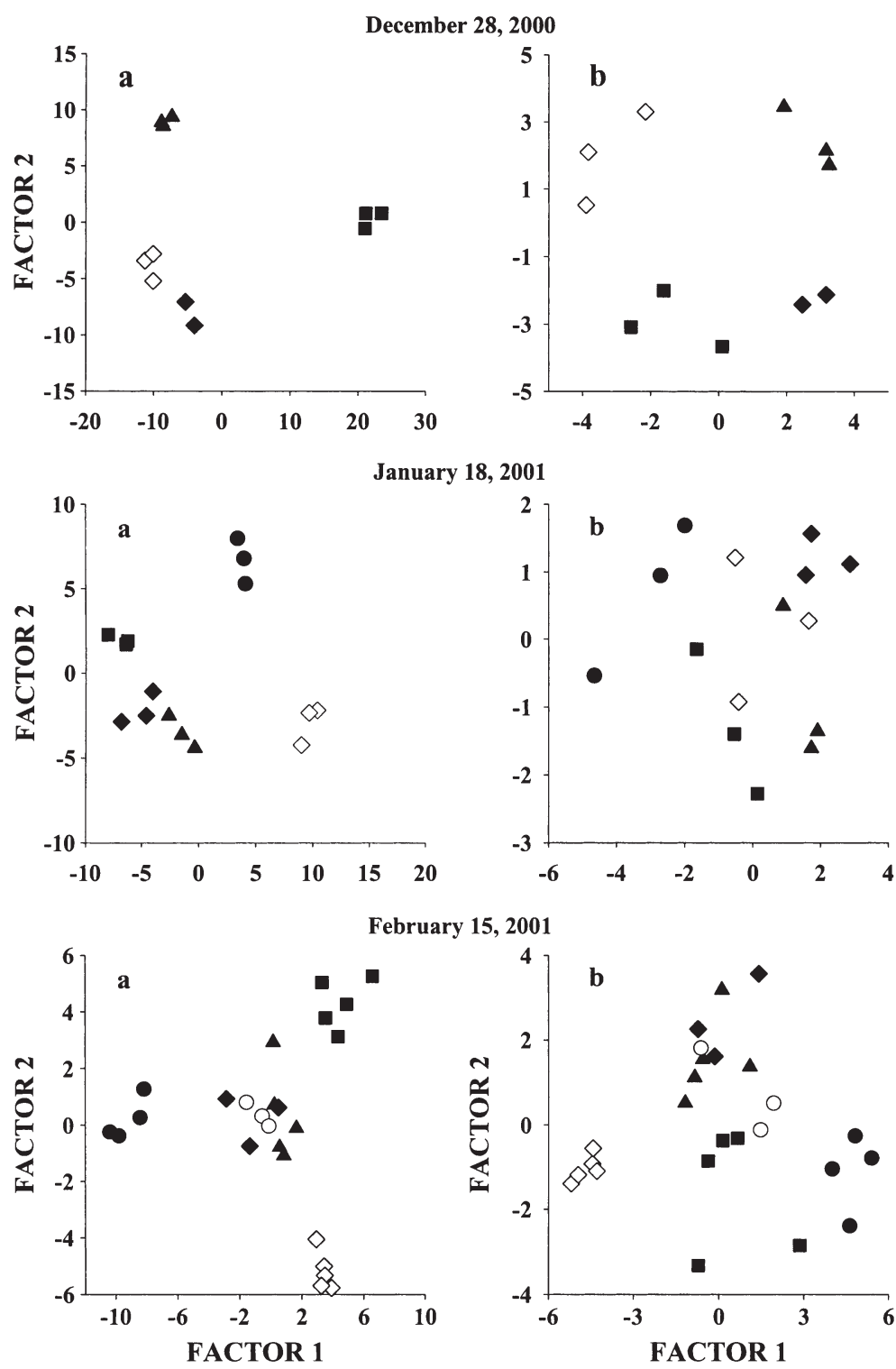

Fig. 3. Plots of the first 2 discriminant analysis scores for (a) marker pigments and for (b) algal classes calculated by the CHEMTAX program from marker pigments. Initials $(\diamond)$, controls $(\diamond)$ and symbols of the copepod species are shown in Fig. 1 clausi fed mainly on chlorophytes and diatoms, E. acutifrons on diatoms and chlorophytes, T. longicornis on dinoflagellates and diatoms, and $O$. nana on dinoflagellates and prymnesiophytes (Fig. 5). Therefore, selectivity index values corroborate the selective feeding behaviour showed by discriminant analyses.

Fig. 6 shows that there was a significant relationship $\left(F_{1,4}=15.9, r^{2}=0.8, \mathrm{p}=0.016\right)$ between similarity among the copepod species in the scores of the discriminant analyses performed on the AAC of copepods (Fig. 1) and those on the marker pigments in February 2001 (Fig. 3a). In January, there was also a positive relationship but this was not significant $\left(F_{1,1}=17.0, r^{2}=0.94, \mathrm{p}=0.152\right)$, probably due to the low number of data. Therefore, it seems that those copepod species with a similar diet had a similar AAC, which could indicate that the differences in AAC among copepod species are due to different food resources.

\section{DISCUSSION}

Both marker pigments and AAC of copepods are good indicators of copepod diet in field studies. Therefore, both organic markers can be used for the study of trophic relationships in pelagic copepod communities, especially in habitats such as the Ría de Vigo, where during some times of the year the phytoplankton community is dominated by small phytoplankton that cannot be identified by microscopic counting.

There are several advantages in using AAC over marker pigments. First, AAC is an indicator of both autotrophic and nonautotrophic food required by copepods for optimal reproduction, whereas marker pigments is only an indicator for the autotrophic food ingested by copepods. Second, in bottle incubation feeding experiments, it is assumed that pigments are destroyed during feeding so the decreases in pigment represent grazing rates. However, phytoplankton pigments are not conserved during copepod grazing and, hence, there is no constant value for the extent to which they are destroyed, as this variability in pigment destruction can be attributed to algal species, algal concentration and ingestion rates (McLeroyEtheridge \& McManus 1999). Therefore, an additional problem in the use of marker pigments could be that undestroyed pig- 

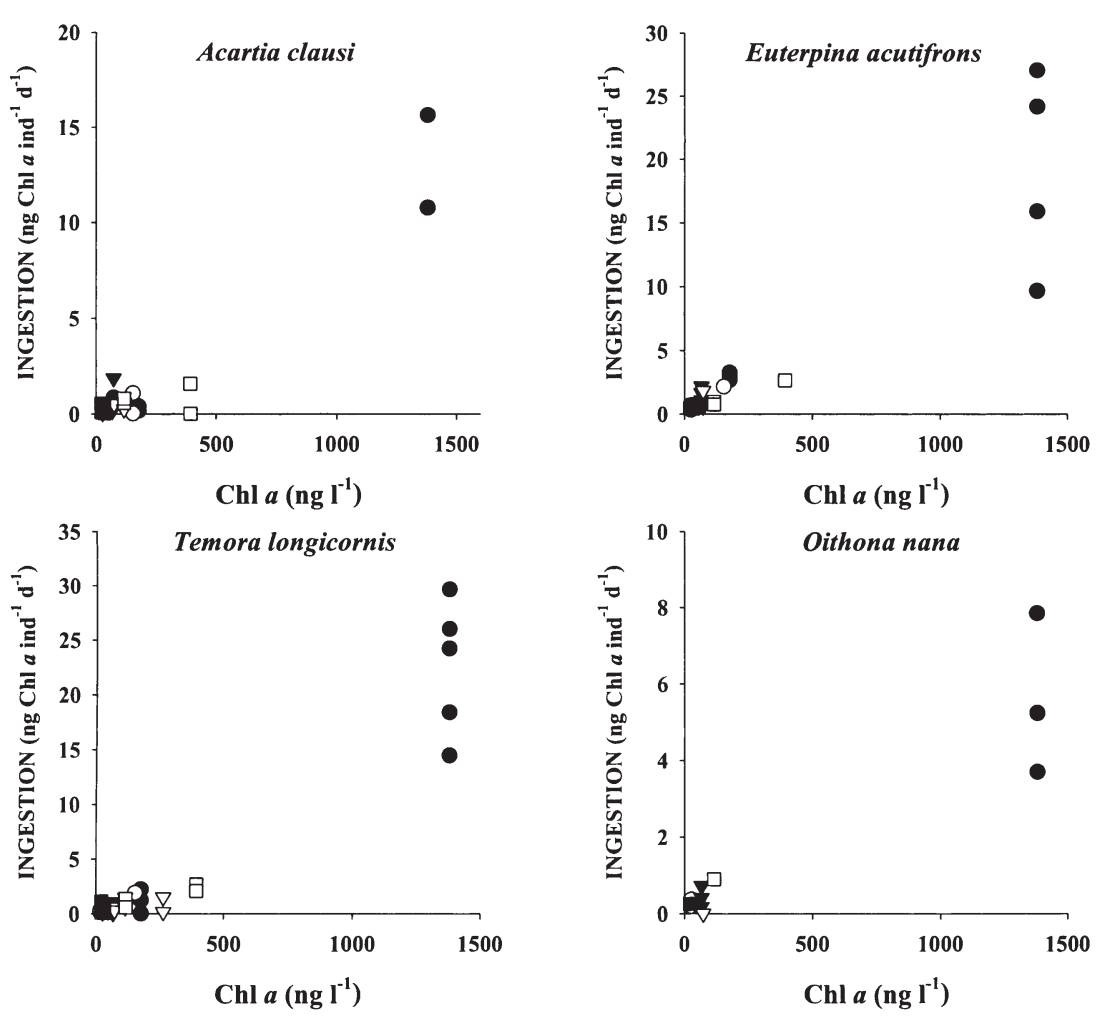

Fig. 4. Relationships between taxon-specific ingestion and abundance for the different phytoplankton groups. Diatoms $(\bullet)$, dinoflagellates (०), prymnesiophytes $(\boldsymbol{\nabla})$, chryptophytes $(\nabla)$, chlorophytes $(\boldsymbol{\square})$ and prasinophytes $(\square)$

having a different diet. It has been shown that copepods can assimilate AA selectively (Cowie \& Hedges 1996). However, an experiment carried out with Euterpina acutifrons fed on monoalgal diets showed a higher production efficiency of copepods when the food source had a similar AAC to that of the copepod (Guisande et al. 1999, 2000), indicating that the selective retention of AA is not enough to convert the food ingested into a biomass with a relatively strict species-specific AAC. This could be due to the short gut residence time of ingested food observed in copepods (<30 min), which results in the more highly assimilated material being that which is the most abundant in the cytoplasm of the food (Reinfelder \& Fisher 1991). If AAC of the food is too different from the AAC of females, the lag time between food being ingested and then converted into egg production is probably too short to allow this, as the AAC is not compatible enough for optimal AA levels (Guisande et al. 1999, 2000). That is probably why AAC of the eggs varied according to food source and, as the AAC of eggs is more similar to the AAC of females, a higher naupliar production is obtained (Guisande et al. 1999, 2000), corroborating the importance of AAC

ments inside faecal pellets could lead to a grazing underestimation of some specific phytoplankton groups. Finally, analyses of copepod AAC do not require incubation of the copepods, so possible artefacts associated with bottle incubation feeding experiments are avoided. The main problem of AAC is that it does not provide information about taxon-specific grazing of copepods; therefore, it is not possible to obtain information about the ingestion rates on specific groups of the phytoplankton community, which is important for food web studies. Hence, AAC of copepods seems to be a good technique for studies about food resources competition among copepod species, whereas marker pigments are useful for studies about flows of energy and material through food webs.

In a series of experiments performed on cultures with unialgal diets, Guisande et al. (1999) observed that AAC of the copepod Euterpina acutifrons remained constant, despite variations in the AAC of the diet. Our field study shows that each copepod species has a specific AAC that also remained relatively constant over the year despite possible changes in nutritional supplies. The differences in AAC among the copepod species could be due to a different selective retention of AA between the species and/or to copepod species of the food and copepod reproduction (Kleppel et al. 1998). Therefore, to maximise reproductive success, copepods should ingest food with an AAC similar to

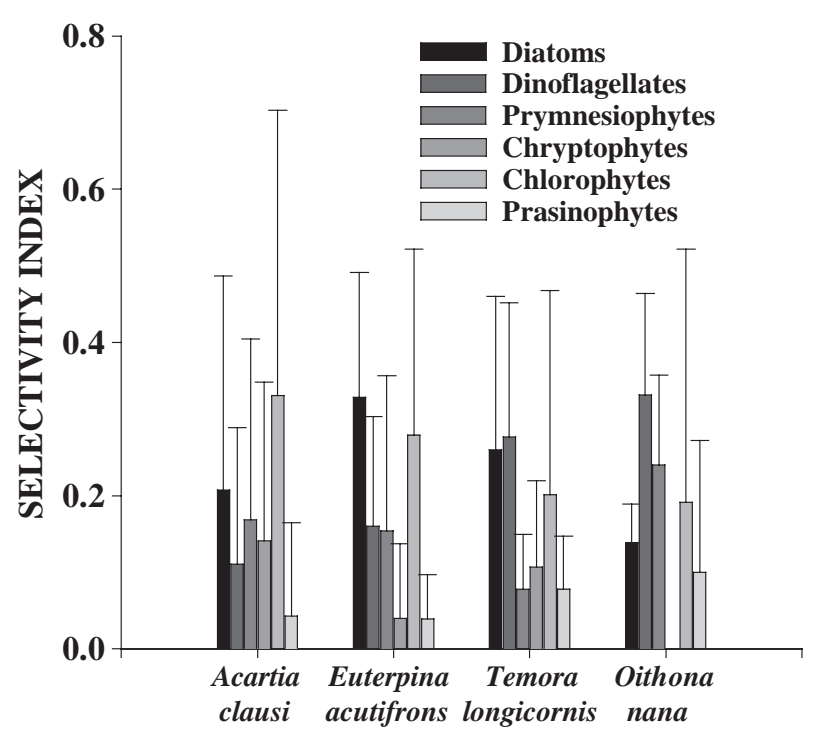

Fig. 5. Selectivity index values $\left(\alpha_{i}\right.$, mean \pm SD) for the different phytoplankton groups for the 3 sampling days 

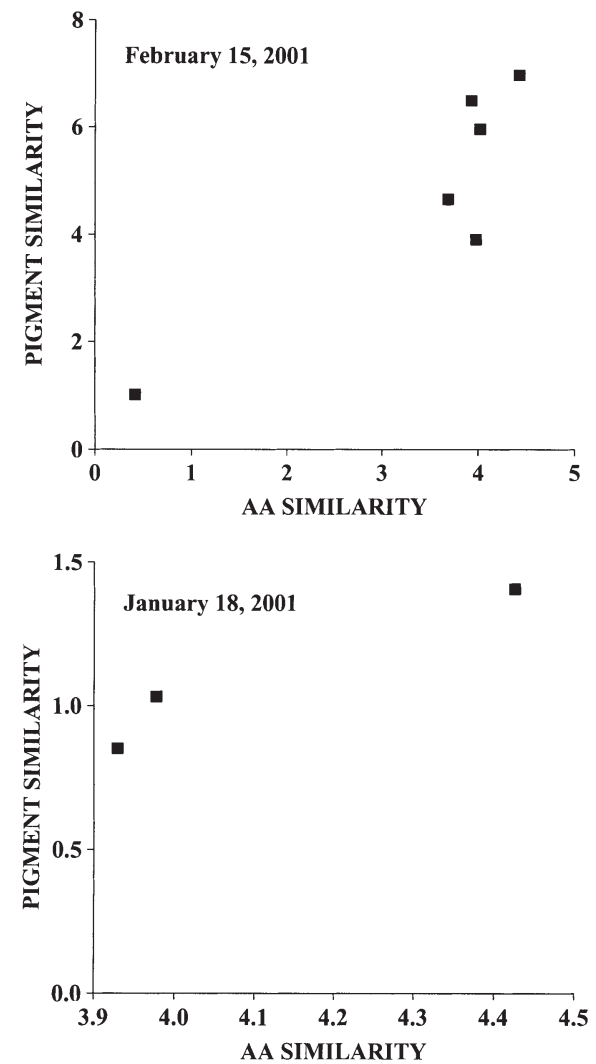

Fig. 6. Relationship between similarity among the amino acid composition of copepod species (Fig. 1) and similarity among the marker pigments (Fig. 3a) in January and February 2001. Similarity was measured by Euclidean distance

theirs, which means that there should be some kind of food selection by copepod species.

There is strong evidence that copepods are selective feeders (DeMott 1989, Kleppel 1993). Food selection can be based on size, shape and/or chemical criteria. As it has been shown that handling time for suspensionfeeding zooplankton is not a limiting factor (Lehman 1976, DeMott 1989), rejection of numerous poor quality particles need not interfere with feeding on high quality items and, hence, nutritional benefit can be maximised by food selection based on particle quality. Additionally, copepods are thought to use chemical cues to assess the quality of individual food items, which is precisely the kind of ability required by optimal diet theory (DeMott 1989). Copepods can discriminate between different food items on the basis of particle size, algalflavoured and unflavoured artificial particles, live and dead algae of the same species, and algae that differ in digestibility and toxic phytoplankton (see DeMott 1989). However, copepods can also discriminate between more subtle chemical differences such as cell nitrogen content of phytoplankton species (Cowles et al. 1988) and, furthermore, AA have been shown to act as stimulatory compounds influencing feeding behaviour in some copepod species (Poulet \& Marsot 1980).

Controlled experiments frequently corroborated the idea that copepods are selective feeders (Cowles et al. 1988, DeMott 1989). Meyer-Harms \& von Bodungen (1997) showed, in an estuary where food quantity was high, that the quality of the algae was responsible for food selection because many species were similar in size to algae that were selected by Acartia bifilosa. However, other field studies have shown indiscriminate grazing in copepods (see Turner \& Tester 1989). In nature, even contradictory results are also obtained for related species of the same genus. Meyer-Harms et al. (1999) found selective feeding behaviour for Calanus finmarchicus in the Norwegian Sea, whereas Irigoien et al. (2000) showed non-selective feeding behaviour for Calanus helgolandicus in the English Channel.

Our results obtained from marker pigments in incubation feeding experiments corroborate the hypothesis that copepod species fed selectively on phytoplankton groups and, moreover, that copepod species have different diets. The relationship between similarities among copepod species in AAC and marker pigments (Fig. 6) confirms that the differences in AAC among copepod species are due to different food resources. This relationship between similarities among copepod species in AAC and marker pigments is probably due to the low abundance of non-autotrophic food in the size fraction $<100 \mu \mathrm{m}$. If the proportion of nonautotrophic food were higher, there would probably not be a clear relationship between similarities among copepod species in AAC and marker pigments, because AAC of copepods indicates both the autotrophic and non-autotrophic food needed by copepods for optimal reproduction.

As AAC of copepod species is relatively constant and a higher reproductive success is achieved when the AAC of the food ingested is similar to that of the copepods, the selective feeding behaviour on available food could be due to the necessity to have an optimally proportioned AA diet. This would corroborate optimal foraging theory (DeMott 1989), which is based on the idea that individual consumers should maximise individual fitness through their foraging behaviour.

We conclude that the AAC of copepod species is an indicator of the quality of food (both autotrophic and non-autotrophic food) that copepods require in their diet for optimal reproductive success. Food niche differences due to differential overlap of the proportion of AA that copepods require in their diet might contribute to the coexistence of these copepod species in their habitat. Therefore, these 4 co-occurring copepod species seem to avoid competition through differential diet overlap and, hence, niche separation of these co-occurring copepod species is partly due to trophic partitioning. 
Acknowledgements. We thank M. D. Mackey for a copy of the CHEMTAX program. This research was supported by an FPU grant to I.M. and a grant from FUNDACIÓN PROVIGO to I.R.

\section{LITERATURE CITED}

Bodgan KG, Gilibert JJ (1987) Quantitative comparison of food niches in some freshwater zooplankton: a multi-tracercell approach. Oecologia 72:331-340

Cowie GL, Hedges JI (1996) Digestion and alteration of the biochemical constituents of a diatom (Thalassiosira weissflogii), ingested by an herbivorous zooplankton (Calanus pacificus). Limnol Oceanogr 41:581-594

Cowles TJ, Olson RJ, Chrisholm SW (1988) Food selection by copepods: discrimination on the basis of food quality. Mar Biol 100:41-49

DeMott WR (1989) Optimal foraging theory as a predictor of chemically mediated food selection by suspension-feeding copepods. Limnol Oceanogr 34:140-154

Donaghay PL, Small FL (1979) Food selection capabilities of the estuarine copepod Acartia clausi. Mar Biol 52: $137-146$

Edler L (1979) Recommendations for marine biological studies in the Baltic Sea. Phytoplankton and chlorophyll. BMP Publ 5:1-38

Frost BW (1972) Effects of size and concentration of food particles on the feeding behaviour of the marine planktonic copepod Calanus pacificus. Limnol Oceanogr 17:805-815

Guisande C, Maneiro I, Riveiro I (1999) Homeostasis in the essential amino acid composition of the marine copepod Euterpina acutifrons. Limnol Oceanogr 44:691-696

Guisande C, Riveiro I, Maneiro I (2000) Comparisons among the amino acid composition of the females, eggs and food to determine the relative importance of food quantity and food quality to copepod reproduction. Mar Ecol Prog Ser 202:135-142

Hansen, Bjornsen BPK, Hansen PJ (1994) The size ratio between planktonic predators and their prey. Limnol Oceanogr 39:395-403

Hillebrand H, Dürselen CL, Kirschel D, Pollinger U, Zohary $\mathrm{T}$ (1999) Biovolume calculation for pelagic and benthic microalgae. J Phycol 35:403-424

Irigoien X, Head RN, Harris RP, Cummings D, Harbour D (2000) Feeding selectivity and egg production of Calanus helgolandicus in the English Channel. Limnol Oceanogr 45:44-54

Kinne O (1977) Cultivation of marine organisms: water-quality management and technology. In: Kinne $\mathrm{O}$ (ed) Marine ecology: a comprehensive, integrated treatise on life in oceans and coastal waters. Vol III, Part 2. Wiley-Liss, New York, p 19-200

Kleppel GS (1993) On the diets of calanoid copepods. Mar Ecol Prog Ser 99:183-195

Kleppel GS, Burkart CA, Carter K, Tomas C (1996) Diets of calanoid copepods on the West Florida continental shelf: relationships between food concentration, food composition and feeding activity. Mar Biol 127:209-217

Kleppel GS, Burkart CA, Houchin L (1998) Nutrition and the regulation of egg production in the calanoid copepod Acartia tonsa. Limnol Oceanogr 43:1000-1007

Lehman JT (1976) The filter feeder as a optimal forager, and the predicted shapes of feeding curves. Limnol Oceanogr 21:501-516

Mackey MD, Mackey DJ, Higgins HW, Wright SW (1996)

Editorial responsibility: Otto Kinne (Editor),

Oldendorf/Luhe, Germany
CHEMTAX - a program for estimating class abundance from chemical markers: application to HPLC measurements of phytoplankton. Mar Ecol Prog Ser 144:265-283

Manly BFJ (1974) A model for certain types of selection experiments. Biometrics 30:281-294

McLeroy-Etheridge SL, McManus GB (1999) Food type and concentration affect chlorophyll and carotenoid destruction during copepod feeding. Limnol Oceanogr 44: 2005-2011

Menden-Deuer S, Lessard EJ (2000) Carbon to volume relationships for dinoflagellates, diatoms, and other protist plankton. Limnol Oceanogr 45:569-579

Meyer-Harms B, von Bodungen B (1997) Taxon-specific ingestion rates of natural phytoplankton by calanoid copepods in an estuarine environment (Pomeranian Bight, Baltic Sea) determined by cell counts and HPLC analyses of marker pigments. Mar Ecol Prog Ser 153:181-190

Meyer-Harms B, Irigoien X, Head RN, Harris RP (1999) Selective feeding on natural phytoplankton by Calanus finmarchicus before, during and after the 1997 spring bloom in the Norwegian Sea. Limnol Oceanogr 44:154-165

Poulet SA, Marsot P (1980) Chemosensory feeding and foodgathering by omnivorous marine copepods. In: Kerfoot WC (ed) Evolution and ecology of zooplankton communities. University Press of New England, Lebannon, NH, p 198-218

Reinfelder JR, Fisher NS (1991) The assimilation of elements ingested by marine copepods. Science 251:794-796

Rodriguez F, Varela M, Zapata M (2002) Phytoplankton assemblages in the Gerlache and Bransfield Straits (Antarctic Peninsula) determined by light microscopy and CHEMTAX analysis of HPLC pigment data. Deep-Sea Res II 49:723-747

Schlüter L, Mohlenberg F, Havskum H, Larsen S (2000) The use of phytoplankton pigments for identifying and quantifying phytoplankton groups in coastal areas: testing the influence of light and nutrients on pigment/chlorophyll $a$ ratios. Mar Ecol Prog Ser 192:49-63

Turner JT, Tester PA (1989) Zooplankton feeding ecology: non selective grazing by the copepods Acartia tonsa Dana, Centropages velificatus De Oliveira, and Eucalanus pileatus Giesbrecht in the plume of the Mississippi River. J Exp Mar Biol Ecol 126:21-43

Van Wandelen CH, Cohen SA (1997) Using quaternary highperformance liquid chromatography eluent systems for separating 6-aminoquinolyl-N-hydroxysuccinimidyl carbamate-derivated amino acid mixtures. J Chromatogr 763 : $11-22$

Wright SW, Thomas DP, Marchant HJ, Higgings HW, Mackey MD, Mackey DJ (1996) Analysis of phytoplankton of the Australian sector of the Sourthern Ocean: comparisons of microscopy and size frequency data with interpretations of pigment HPLC data using the 'CHEMTAX' matrix factorisation program. Mar Ecol Prog Ser 144:285-298

Zapata M, Freire J, Garrido JL (1998) Pigment composition of several harmful algae as determined by HPLC using pyridine-containing mobile phases and a polymeric octadecylsilica column. In: Reguera B, Blanco J, Fernández ML, Wyatt T (eds) Harmful algae. Proc 8th Int Conf on Harmful Algae. Intergovernmental Oceanographic Commission of UNESCO, Paris, p 304-307

Zapata M, Rodríguez F, Garrido JL (2000) Separation of chlorophylls and carotenoids from marine phytoplankton: a new HPLC method using a reversed phase $\mathrm{C}_{8}$ and pyridine containing mobile phases. Mar Ecol Prog Ser 195: 29-45

Submitted: November 8, 2001; Accepted: April 18, 2002

Proofs received from author(s): July 30, 2002 